\title{
TABARAK METHOD AS A MEANS OF DA'WA TO MAKE IT EASIER FOR CHILDREN TO MEMORIZE THE QURAN
}

\author{
Nur Lailatul Musyafa'ah ${ }^{1}$, Fathin Masyhud ${ }^{2}$ \\ 1,2Sunan Ampel State Islamic University \\ 1nurlailatul@uinsby.ac.id, 2fathin695@gmail.com
}

\begin{abstract}
Teaching children about reading and memorizing the Quran is part of da'wa to children. Today many Muslim families want their children can be memorizers of the Quran. Therefore, various kinds of tahfiz methods have been sprung for children, including the Tabarak method. This research investigates how the Tabarak method becomes a means of da'wa to facilitate tahfiz Quran for children. This research uses a qualitative approach with this type of literature study research. In general, the findings of this study show that the Tabarak method can be used as a means of da'wa for children to memorize the Quran quickly. That is indicated by the positive reception of children who perform tahfiz with the Tabarak method. In addition to many parents who accompany their children can also memorize the Quran as memorized by their children. With the support of the family, children can memorize the Quran and live a better life because the Quran guides what they learn. The training was held to expand the spread of the Tabarak method, especially for facilitators of tahfiz Markaz, managers, and parents. The promotion of the Tabarak method is also done through social media such as WhatsApp groups, Facebook, and Instagram.
\end{abstract}

Keywords: Tabarak Method, Da'wa, Tahfiz Al-Quran, Children.

\begin{abstract}
Abstrak: Mengajarkan anak tentang membaca dan menghafal al-Quran adalah bagian dari dakwah kepada anak-anak. Saat ini banyak keluarga muslim yang menginginkan anaknya bisa menjadi penghafal al-Quran. Karena itu bermunculan berbagai macam metode tahfiz bagi anak-anak, di antaranya metode Tabarak. Penelitian ini bertujuan untuk mengungkap bagaimana metode Tabarak menjadi sarana dakwah untuk memudahkan tahfiz al-Quran bagi anak-anak. Penelitian ini menggunakan pendekatan kualitatif dengan jenis penelitian studi pustaka. Secara umum temuan penelitian ini menunjukkan bahwa metode Tabarak dapat digunakan sebagai sarana dakwah bagi anak-anak agar dapat menghafal al-Quran dengan mudah. Hal itu ditunjukkan dengan adanya penerimaan positif dari anak-anak yang melakukan tahfiz dengan metode Tabarak. Di samping itu, banyak orang tua yang mendampingi anak-anaknya juga bisa menghafal al-Quran sebagaimana hafalan anaknya. Dengan dukungan keluarga, anakanak mampu menghafal al-Quran dan menjalani hidup dengan lebih baik karena berpedoman pada al-Quran yang dipelajarinya. Untuk memperluas penyebaran metode Tabarak ini, maka diadakan pelatihan-pelatihan khususnya bagi fasilitator markaz tahfihz dan orang tua. Promosi metode Tabarak juga dilakukan melalui media sosial seperti grup whattsap, Facebook, dan Instagram.
\end{abstract}

Kata Kunci: Metode Tabarak, Dakwah, Tahfiz Al-Quran, Anak-anak. 


\section{A. Introduction}

Preaching to children is very important. If they do not have coaching and mentoring, then it can lead to delinquency or deviant behavior. ${ }^{1}$ Each year, child delinquency cases in Indonesia have increased significantly, 2 from mild failure to criminal acts. ${ }^{3}$ Imam Khoiri's research results in East Java in 2019 contained 143 child inmates, with cases dominated by drug abuse as much as 51 percent were drug users and addicts were still children or teenagers under 19 years old, followed by issues of prostitution, gangsters, and others. ${ }^{4}$

Child delinquency to criminal acts is feared to be a pattern of behavior that has the potential to persist and repeat that can damage social, academic, and future functions. ${ }^{5}$ Several contributing factors most influence the onset of juvenile delinquency or crime: environmental, social, economic, and psychological factors. ${ }^{6}$ Sri Wahyuni's research states that the delinquency factor of adolescents is due to the lack of parental attention in their children, more minor examples than parents, and lack of religious education in the family. ${ }^{7}$ For this reason, construction is required for the child done with compassion and compassion 8 and good teaching and education. ${ }^{9}$ In addition, proper da'wa is needed among children to overcome delinquency, ${ }^{10}$ with Q\&A, discussion, and lectures. ${ }^{11}$ These efforts are inseparable from the basic concept of da'wa methods that remain based on da'wa bi al-hal, bi al-lisan, and bi al af'al.12

Preaching to children can be done from the time they are early. The da'wa that needs to be taught is to read the Quran since the child is in the womb. ${ }^{13}$ Religious education is an important thing that needs to be introduced to children. The Quran, as the holy book of Muslims, becomes part of the teachings of the religion that must be taught to children. In addition to reading, Muslims are encouraged to memorize the Quran. Many educational institutions teach the tahfiz al-Quran

\footnotetext{
${ }^{1}$ Sarmin Husaini, "Strategi Dakwah Dalam Meminimalisir Kenakalan Remaja Di Kelurahan Katangka Kab. Gowa" (Universitas Muhammadiyah Makassar, 2019), 6.

${ }^{2}$ Riamah and Elfa Zuriana, "Faktor-Faktor Yang Mempengaruhi Terjadinya Kenakalan Remaja," Menara Ilmu XII, no. 10 (2018): 113.

${ }^{3}$ Angga Prayuda, "Peran Kepolisian Sektor Simpang Kanan Dalam Menanggulangi Kenakalan Remaja" (Universitas Islam Negeri Sultan Syarif Kasim Riau, 2021), i.

${ }^{4}$ Ahmad Imam Khairi, "Masyarakat Modern Dan Kenakalan Remaja: Suatu Telaah Sosial," ENTITA: Jurnal Pendidikan Ilmu Pengetahuan Sosial Dan Ilmu-Ilmu Sosial 2, no. 1 (2020): 147, https://doi.org/10.19105/ejpis.v1i2.3243.

${ }^{5}$ Khanif Maksum and Ahmad Syamsul Arifin, "Pola Pendekatan Penanganan Gangguan Perilaku (Conduct Disorder) Pada Pelajar SD: Sebuah Upaya Mengurangi Perilaku Kekerasan Pelajar Di Yogyakarta," MODELING: Jurnal Program Studi PGMI Volume 6, no. 2 (2019): 260.

${ }^{6}$ Ni Putu Rai Yuliartini, "Kenakalan Anak Dalam Fenomena Balapan Liar Di Kota Singaraja Dalam Kajian Kriminologi," Jurnal Advokasi 9, no. 1 (2019): 38.

7 Sri Wahyuni Kadir, Nursalam, and Muhammad Akhir, "Peranan Polisi Sektor Kajuara Dalam Menanggulangi Kenakalan Remaja," Fenomena Plagiarisme Mahasiswa IV, no. 1 (2016): 91, https://media.neliti.com/media/publications/70308-ID-fenomena-plagiarisme-mahasiswa.pdf.

${ }^{8}$ Ria Juliana and Ridwan Arifin, "Anak Dan Kejahatan (Faktor Penyebab Dan Perlindungan Hukum)," Jurnal Selat 6, no. 2 (2019): 225, https://doi.org/10.31629/selat.v6i2.1019.

${ }_{9}$ M. Sanusi, Nurhasanah, and Nurbaity, "Hubungan Komitmen Pendidikan Diniah Dengan Perilaku Menyimpang Pada Remaja," Jurnal Ilmiah Mahasiswa Bimbingan Dan Konseling 2, no. 2 (2017): 57, http://linkinghub.elsevier.com/retrieve/pii/S0167273817305726\%0Ahttp://dx.doi.org/10.1038/s4146 7-017-01772-

1\%0Ahttp://www.ing.unitn.it/ luttero/laboratoriomateriali/RietveldRefinements.pdf\%0Ahttp://www.i ntechopen.com/books/spectroscopic-analyses-developme.

${ }_{10}$ Novita Sugiestian, "Peran Dakwah Dalam Problematika Masa Remaja," OSF PREPRINTS, 2012, 7, https://doi.org/10.31219/osf.io/c7xwh.

11 Fahmi, "Peranan Dakwah Dalam Meminimalisir Kenakalan Remaja Di Kecamatan Bati-Bati Kabupaten Tanah Laut" (UIN Antasari Banjarmasin, 2020), vi, http://repositorio.unan.edu.ni/2986/1/5624.pdf.

${ }^{12}$ Akhmad Sukardi, "Metode Dakwah Dalam Menangani Problematika Remaja," Al-Munzir 9, no. 1 (2016): 12, https://ejournal.iainkendari.ac.id/index.php/al-munzir/article/view/774/705\#.

${ }^{13}$ Siti Hikmah, "Mengenalkan Dakwah Pada Anak Usia Dini," Jurnal Ilmu Dakwah 34, no. 1 (2014): 63-76.
} 
to children or adults with various methods, 14 such as the Utrujah method, 3T+1M method, Tawazun method, Quantum Tahfiz Quran method, Tabarak method, and other methods. ${ }^{15}$ Each method has its drawbacks and advantages, so varied ways can complement each other and eliminate boredom. In addition, the use of several methods has the opportunity to strengthen memorization. 16

The Tabarak method is one of the tahfiz methods for children taught in Indonesia. The Tabarak method is a tahfiz method initiated by Dr. Kamil El-Laboudy from Egypt. The name Tabarak was taken after their first son, Tabarak, who managed to memorize the Quran at 4.5 years. Their second son, Yazid, also successfully became a memorizer of the Quran at the age of 4.5 years, and their third daughter, Zeenah, became a memorizer of the Quran at the age of 5.17

Based on this success, Dr. Kamil el-Laboudy wanted to divide and disseminate the methods used in teaching his son tahfiz to Muslims by creating the Tabarak Project.18 This Tabarak project has the motto"La tathib al-hayah illa bi Kitab Allah" (With the Quran, your life must be good). The Tabarak project is already registered with the Ministry in Egypt. ${ }^{19}$ Although it originated in Egypt, the Tabarak project has gone global. Based on data from tahfiz institutions in Indonesia as of January 22, 2019, 198 tahfiz institutions use the Tabarak method. ${ }^{20}$

Some research results show that the Tabarak method proved effective in memorizing children to memorize the Quran including at Club Tahfidh Genta Quran Bubutan Surabaya, ${ }^{21}$ in Markaz Al-Firdaus, ${ }^{22}$ in MATABA al Furqon Petung Panceng Gresik, ${ }^{23}$ at SDIT Huda Wan Nur Langsa City and in Tahfiz Shohibul Quran Manado House. ${ }^{24}$ Hailatur Rosyidah's research showed that the Tabarak method was effectively used to guide teenagers in memorizing the Quran at the House of Tahfiz Gemilang Ash-Shiddiq Salatiga. ${ }^{25}$ Even the Hit method is effectively used in the House of Tahfiz Toddler and Child Shohibul Quran to hone the ability to speak, read, and write through training children with Speech Delay memorizing the Quran using the Tabarak Method.26 Andarini's research concluded that memorizing the Quran improves the memory of remembering the Quran in early childhood.27

\footnotetext{
${ }^{14}$ Nurul Hidayah, "Strategi Pembelajaran Tahfidz Al-Qur'an Di Lembaga Pendidikan," Ta'allum: Jurnal Pendidikan Islam 4, no. 1 (2016): 63, https://doi.org/10.21274/taalum.2016.4.1.63-81.

15 Hidayah, 63.

${ }^{16}$ Hidayah, 74.

${ }^{17}$ Fathin Masyhud and Ida Husnur Rahmawati, Rahasia Sukses 3 Hafizh Qur'an Cilik Mengguncang Dunia (Jakarta: Zikrul Hakim, 2019), 22-24.

${ }^{18}$ Kamil el Laboudy, "Muzakarah Al-Daurah Al-Tadribiyyah Li Manhaj Tabarak Al-Marhalah Al-Ula” (Jakarta: YIKTY, 2019), 3.

19 Ibid.

20 “Daftar Lembaga Tahfidz Quran Metode Tabarak Di Indonesia," 2019.

${ }^{21}$ Masrudin Lau, "Evektifitas Metode Tabarok Dalam Memepercepat Anak Menghafal Al-Qur'an Di Club Tahfid Genta Qur'an Bubutan Surabaya," Revista Brasileira de Geografia Física (Universitas Muhammadiyah Surabaya, 2016), vii, http://biblioteca.ibge.gov.br/visualizacao/monografias/GEBIS - RJ/RBG/RBG 1995 v57_n1.pdf\%0Ahttps://periodicos.ufpe.br/revistas/rbgfe/article/view/234295.

${ }^{22}$ Roza Nurma Putri Juwita, "Efektivitas Metode Tabarak Dalam Pembelajaran Tahfiz Al-Quran Pada Balita Di Markaz Al-Firdaus Candi Sidoarjo" (Universitas Muhammadiyah Sidoarjo, 2018).

${ }^{23}$ Rifdatul Maula, "Implementasi Metode Tabarak Di Mataba Al Furqon Desa Petung Panceng Gresik Dan Metode Talaqqi Di KB-TK Al Furqon Al Islami Desa Srowo Sidayu Gresik" (Pascasarjana UIN Sunan Ampel Surabaya, 2019), ix.

${ }^{24}$ Marlista, "Efektivitas Metode Tabarak Dalam Meningkatkan Memori Menghafal Al-Qur'an Pada Anak Usia Dini Di Rumah Tahfidz Shohibul Qur'an Manado" (IAIN Manado, 2020), xvii.

${ }^{25}$ Hailatur Rosida, "Penerapan Metode Tabarak Dalam Meningkatkan Hafalan Para Remaja Di Rumah Tahfidz Gemilang Indonesia Cabang Salatiga" (Fakultas Tarbiyah Dan Ilmu Keguruan Institut Agama Islam Negeri Salatiga, 2020), xv.

${ }^{26}$ Siti Anna Farhiana Abdillah, "Implementasi Metode Tabarak Dalam Pembelajaran Menghafal Al-Qur'an Pada Anak Hambatan Speech Delay Di Rutaba Shohibul Qur'an” (Universitas Negeri Malang, 2020).

${ }^{27}$ Nurul Hidayah Andarini, "Pengaruh Menghafal Al-Qur'an Metode Tabarak Terhadap Peningkatan Memori Menghafal Al-Qur'an Pada Anak Usia Dini” (Universitas Islam Negeri Maulana Malik Ibrahim, 2018), xvi,
} 
Mudhakiroh's research shows that the contributing factors supporting the application of the Tabarak method in memorizing the Quran are that the teacher and student have a healthy soul, motivation, time management and have one type of mushaf for memorization. The inhibiting factors are indiscipline in using time, no room barrier between the student son and daughter, and a place to memorize the Quran that is too crowded with vehicles. ${ }^{28}$ While Alivanie mentions that supporting actors in the learning of tahfiz Quran with the Tabarak method are the teacher aware of the child's fitrah, the role of parents. Active and the teacher performs by time management. While inhibiting factors, poor child motivation, environmental conditions less supportive, and a less conducive learning process in the future. This pandemic. ${ }^{29}$ In addition, conducive rooms, friendly teacher, good tahsin, tahfiz teacher, adequate facilities and infrastructure, and parental support in memorization activities of the Quran are essential to support the success of tahfiz Quran with the Tabarak method. While the five factors inhibiting learning are children's lack of focus when memorizing, being late to school, parents who are busy working, so they do not control and murajaah with their children. ${ }^{3031}$

Based on the background of the problem, it is further necessary to reveal the concept da'wa Tabarak method in spreading the ease and teachings of tahfiz Quran to children.

\section{B. Theoretical Review}

The theory studied in this study is about the concept of da'wa in Islam and toddler tahfiz.

\section{The Concept of Da'wa for Children}

Da'wa is inviting or calling to do good and prevent impossibility. Transform people from one situation to another better in all fields, realize the teachings of Islam in everyday life for a person, family, group, or mass, and for community life as a whole of standard order in the framework of the nation and human development. ${ }^{32}$

Preaching is an obligation for every Muslim and Muslim woman, both everywhere, anytime, and to anyone. Currently, the use of media is an essential element in preaching. Preaching through social media has its challenges for preachers in particular and Muslims in general. ${ }^{33}$

Da'wa and social reality have a solid interdependence relationship related to interdependency. There are at least two critical things that can be expressed from the relationship, namely: first, social reality is a measuring tool for the success of da'wa, which is also a social mirror in formulating the da'wa agenda at the next stage; Second, da'wa activities themselves are essentially a strategic choice in shaping the direction of community change in

http://dx.doi.org/10.1053/j.gastro.2014.05.023\%0Ahttps://doi.org/10.1016/j.gie.2018.04.013\%0Ahttp: //www.ncbi.nlm.nih.gov/pubmed/29451164\%0Ahttp://www.pubmedcentral.nih.gov/articlerender.fcgi? artid=PMC5838726\%250Ahttp://dx.doi.org/10.1016/j.gie.2013.07.022.

${ }^{28}$ Nurul Mudhakiroh, "Metode Menghafal Al-Qur'an Pada Rumah Tahfidz Izzatul Qur'an As'adiyah Dan AlMalik Samarinda" (Program Pascasarjana, Institut Agama Islam Negeri Samarinda, 2020).

${ }^{29}$ Naylusshofy Alivanie, "Strategi Guru Dalam Pembelajaran Menghafal Juz 'Amma Pada Anak Usia Dini Di TK Islam Al Azhar Kepatihan Tulungagung" (Institut Agama Islam Negeri Tulungagung, 2021), xx.

${ }^{30}$ Tendri Herma, Umi Kusyairy, and Muh Rusdi T, "Analisis Penerapan Metode Tabarak Menghafal Al-Qur'an Juz 30 Di Sekolah Tahfidz Al-Husna Balita Dan Anak Makassar," NANAEKE: Indonesian Journal of Early Childhood Education 3, no. 1 (2020): 45, https://doi.org/10.24252/nananeke.v3i1.14332.

${ }^{31}$ Awwaliya Mursyida Lubis and Syahrul Ismet, "Metode Menghafal Alquran Pada Anak Usia Dini Di Tahfidz Center Darul Hufadz Kota Padang," Aulad: Journal on Early Childhood 2, no. 2 (2019): 8, https://doi.org/10.31004/aulad.v2i2.30.

${ }^{32}$ Arief Rachman and Ismi Nadiyati, "Dakwah Melalui Film Animasi," ORASI: Jurnal Dakwah Dan Komunikasi 9, no. 2 (2018): 34, https://doi.org/10.24235/orasi.v9i2.3690.

${ }_{33}$ Mardiana, "Komunikasi Dakwah Kultural Di Era Millenial," Alhadharah: Jurnal Ilmu Dakwah 19, no. 1 (2020): 90-101, http://jurnal.uin-antasari.ac.id/index.php/alhadharah/article/view/3858. 
better order. This ability to read social reality is a very effective first step to developing Islamic da'wa. ${ }^{34}$

One crucial part that must get attention related to education given from an early age is to teach da'wa to children early so that da'wa has become a habit and part of children's lives as adults. Da'wa is an excellent educational process and should refer to Islamic values applied as early as possible to children. If the process can run well, there will be a young generation with a strong commitment. ${ }^{35}$

The da'wa strategy given is the strategy contained in Surah An-Nahl verse 125. There are three things bi al-hikmah (pay attention to the situation and conditions, mauizhah hasanah (giving advice with affection), mujadalah bi allati hiya ahsan (does not give pressures).36 To introduce da'wa to early childhood requires extra patience by understanding the child's condition, such as the cognitive growth process that is still in the formal pre-operational stage, so it requires methods in its application that are easy for children to understand. ${ }^{37}$ The methods used by teachers in this communication are the qishshah (storytelling) method, tajribi (practice) and uswah (exemplary) methods, advice methods, tabshir, and tanzir. The message conveyed is verbal in the form of qaulan baligha, qaulan maisuran, and qaulan sadidan. ${ }^{38}$ According to Rudi Mahmud's research, seven strategies can be used in da'wa to children, namely as follows: storytelling, travel, habituation in acting, playing, role-playing, discussion, example. ${ }^{39}$

In Islam, among the education that must be taught to children is reading and memorizing the Quran. ${ }^{40}$ Teaching children to memorize Quran is necessary with perseverance and patience. In addition, teachers can give praise or reward by saying meek without pressure to remember short surah. The supporting factor of the da'wa strategy in motivating children to memorize the Quran is teachers' activeness and good cooperation from parents. At the same time, the inhibitory factor is an aspect of child intelligence and social environment that is less conducive. ${ }^{41}$

\section{Tahfiz Quran for the Children}

Tahfiz al-Quran consists of two syllables, namely Tahfiz and Quran. Tahfiz is derived from the Arabic word hafizha-yahfazhu-hifzhan, meaning memorization. Memorization is the opposite of forgetting, which is always remembering and a little forget. The Quran is the kalam of Allah (SWT), which is revealed to the Prophet (peace be upon him), delivered to his ummah mutawatir, and beginning from surat al-Fatihah surat an-Nas. ${ }^{42}$

\footnotetext{
${ }^{34}$ Mokhamad Mahfud and Rama Kertamukti, "Desain Komunikasi Dakwah Visual Animasi 2D Untuk AnaK (Studi Deskriptif Kualitatif Di SDN Monggang Pendowoharjo Sewon Bantul)," ProfetikJurnal Komunikasi 09, no. 02 (2016): 45-64.

35 Hikmah, "Mengenalkan Dakwah Pada Anak Usia Dini," 63.

${ }^{36}$ Aminah, "Strategi Dakwah Dalam Memotivasi Anak Untuk Menghafal Surat-Surat Pendek Taman KanakKanak Mandiri Jakabaring” (Universitas Muhammadiyah Palembang, 2019), v.

37 Hikmah, "Mengenalkan Dakwah Pada Anak Usia Dini," 63.

38 Santa Rusmalita, "Internalisasi Nilai-Nilai Dakwah Pada Anak Usia," Al-Hikmah: Jurnal Dakwah 11, no. 2 (2017): 185.

39 Rudi Mahmud, "Strategi Dakwah Pada Anak Usia Dini Di TK Darul Hikmah Desa Tongke-Tongke Kecamatan Sinjai” (UIN Alauddin Makassar, 2018), 60.

${ }^{40}$ Arita Hanim Awang et al., "Physical Learning Ecosystem And Built Environment Of Tahfiz Institutions In Malaysia: A Systematic Review," Journal Of Architecture, Planning \& Construction Management 9, no. 1 (2019): 99-103, https://journals.iium.edu.my/kaed/index.php/japcm/article/view/354.

${ }^{41}$ Aminah, "Strategi Dakwah Dalam Memotivasi Anak Untuk Menghafal Surat-Surat Pendek Taman KanakKanak Mandiri Jakabaring," v.

42 Eva Fatmawati, “Manajemen Pembelajaran Tahfidz Al-Qur'an," ISEMA: Islamic Educational Management 4, no. 1 (2019): 30, https://doi.org/10.15575/isema.v3i2.5255.
} 
The Quran is the holy book of Muslims. He is the source of guidance for humankind, as God says in QS. Al Isra' 15:9: "Surely this Quran gives guidance to the straighter and gives good news to the mu'min who do the deeds that for them there is a great reward." (QS. Al Isra' 15:9).

God has kept the book from all kinds of change. Allah (SWT) also guarantees the maintenance of the Quran and the ease of memorizing it. Muslims are obliged to maintain and maintain it, among others, by reading(al-tilawah), writing (al-kitabah), and remembering (attahfiz). The revelation is always awake and preserved from change and replacement, both surah and the arrangement of words throughout time..$^{43}$ That is by the word of Allah Almighty in surah Al-Hijr verse 09 as follows: "We are the ones who have brought down the Quran, and we are the ones who keep it." (QS. Al-Hijr: 9).

Memorization is one way to maintain the purity of the Quranic verses. ${ }^{44}$ Many verses of the Quran and hadith narration mention glory to the reader and memorizer of the Quran. Among the virtues and glory of memorizing the Quran is: the Quran promises goodness, blessings, and enjoyment for its memorization. The memorizer of the Quran will always be with the noble and obedient angels. On the Day of Resurrection, the Quran will intercede to its readers and memorizers. ${ }^{45}$ The memorization of the Quran belongs to the class of those who are knowledgeable. ${ }^{46}$ The Quran memorizers (Huffaz) have higher intelligence than Huffaz. ${ }^{47}$ Zuhurudeen's research mentions that the Huffaz is easier to understand Arabic than not Huffaz.48

The tradition of memorizing the Quran has been done since the Quran was revealed to the Prophet. At that time, the Arabs did not yet know paper as stationery. The majority of Arabs are still illiterate and cannot read and write. Therefore the Prophet ordered his people to memorize the verses of the Quran. In addition, many can write, write verses in various places such as stones, date palms, or animal bones. The tradition of keeping the Quran in the form of memorization, particularly, continues from generation to generation to the present day. ${ }^{49}$

Memorizing the Quran is a very noble work before humankind and before Allah SWT. ${ }^{50}$ Memorizing the Quran is one of the methods used by the Prophet (peace be upon him) in receiving revelation through the intercession of Jibril (as). ${ }^{51}$ The Talaqqi method is how the Prophet (peace be upon him) exemplified to his companions, tabi'in, and those afterward who all carried out his direct teaching and learning activities or talaqqi. ${ }^{22}$ The talaqqi method is to deposit or listen to a newly memorized memorization to a teacher or instructor. Talaqqi is a way of conveying the

\footnotetext{
43 Ali Akbar and Hidayatullah Ismail, "Metode Tahfidz Al-Qur'an Di Pondok Pesantren Kabupaten Kampar," Jurnal Ushuluddin 24, no. 1 (2016): 92, https://doi.org/10.24014/jush.v24i1.1517.

${ }^{44}$ Hailatur Rosida, "Penerapan Metode Tabarak Dalam Meningkatkan Hafalan Para Remaja Di Rumah Tahfidz Gemilang Indonesia Cabang Salatiga," 2.

${ }^{45}$ Lau, "Evektifitas Metode Tabarok Dalam Memepercepat Anak Menghafal Al-Qur'an Di Club Tahfid Genta Qur'an Bubutan Surabaya," 2.

${ }^{46}$ Andarini, "Pengaruh Menghafal Al-Qur'an Metode Tabarak Terhadap Peningkatan Memori Menghafal AlQur'an Pada Anak Usia Dini," 22.

47 Ahmad A.A. Dzulkarnain, Amirah K. Azizi, and Nur H. Sulaiman, "Auditory Sensory Gating in Huffaz

Using an Auditory Brainstem Response with a Psychological Task: A Preliminary Investigation," Journal of Taibah University Medical Sciences 15, no. 6 (2020): 495-501, https://doi.org/10.1016/j.jtumed.2020.08.007.

${ }^{48}$ Fathima Manaar Zuhurudeen and Yi Ting Huang, "Effects of Statistical Learning on the Acquisition of Grammatical Categories through Qur'anic Memorization: A Natural Experiment," Cognition 148 (2016): 79-84, https://doi.org/10.1016/j.cognition.2015.12.014.

49 Dudi Badruzaman, "Metode Tahfidz Al-Qur'an Di Pondok Pesantren Miftahul Huda II Kabupaten Ciamis," Jurnal KACA 9, no. 2 (2019): 185, https://doi.org/10.29313/idea.v0i0.4888.

${ }^{50}$ Achmad Muslimin, "Implementasi Metode Halaqah Dan Resitasi Dalam Tahfidz Al-Quran Di Sdit El - Haq Banjarsari Buduran Sidoarjo," Adabiyah: Jurnal Pendidikan Islam 1, no. 1 (2011): 56, https://doi.org/10.21070/ja.v1i1.164.

51 Badruzaman, "Metode Tahfidz Al-Qur'an Di Pondok Pesantren Miftahul Huda II Kabupaten Ciamis," 185.

52 Torikhul Wasyik and Abdul Hamid, "Implementasi E-Learning Dalam Pembelajaran Al-Qur'an Era Covid19 Di Sanggar Tahfidz Enterpreuner Krian Sidoarjo,” Edudeena 4, no. 1 (2020): 15.
} 
recitation of the Quran in a mushafahah (the child sees the teacher's lips appropriately) which is directly opposite the student in a sitting position calmly and comfortably. The teacher guides the child to repeat the recited verse by listening until the child is completely memorized. 53

In addition to adults, children are also encouraged to memorize the Quran. In the history of Islam, many scholars have remembered the Quran in childhood. Imam Shafi'i, who remembered the Quran at the age of 7 years, Yusuf al-Qaradawi, memorized the Quran before ten years. Memorizing the Quran since children have many peculiarities: Allah will mix the Quran with his flesh and blood, reward him and his family, and lift bala' from his family. Memorizing Quran in childhood is like carving on a stone and continuing the scholars' traditions. ${ }^{54}$

The main factors of success in memorizing the Quran for children are intention and prayer. ${ }^{55}$ In addition, there are other supporting factors, namely:

1) Understand the character of the child. Children are not separated from playing activities and love gifts. Therefore, children are still allowed to play attractive and fun games, which do not harm themselves and others. In addition, giving praise and gifts must also be done as a form of appreciation and motivation in memorizing the Quran.

2) The role of parents. The role of parents is significant in motivating, supervising, and accompanying children in memorizing the Quran.

3) Time management. All parties must manage time well, namely, memorizing new verses, repeating time, studying, and playing.

4) Istiqomah/continuity. Commitment is essential from all parties so that children can complete their memorization as much as 30 juz. ${ }^{56}$

\section{Methods}

This research is literature and qualitative research. This research is literature research, as data is collected from books, articles, and more. This research is qualitative because the data collected is not based on numbers. The collected information is analyzed descriptively deductively. Based on the general theory of the concept of da'wa and tahfiz Quran to then be used to analyze the Tabarak method in the da'wa of tahfiz Quran for children, to produce a particular conclusion.

\section{Results and Discussion}

\section{Concept of the Hit Method}

The Tabarak method was conceived by Dr. Kamil el-Laboody. Kamil el-Laboody was born in Tanta, Egypt, on January 4, 1976, to coincide with the 3rd of Muharram 1396. He is married to Rasya Abdul Mun'im el-Jayyar, who is also from Tanta. ${ }^{57}$ El-Laboody completed his Pharmacy Degree at Tanta University and continued his Master's education at the UK University of Leicester in Business Management. In 2000 they both traveled to Jeddah and taught at Batterjee Medical College. They live in the old airport area near Jeddah's Sa'id bin Zubeir mosque. El-At first, el-Laboody and his wife underwent a profession as lecturers at the Faculty of Pharmacy and Human Resources Improvement. In addition, he has also been a coach in various training centers both inside and outside Egypt.

\footnotetext{
53 Tika Kartika, "Manajemen Pembelajaran Tahfidz Al-Qur'an Berbasis Metode Talaqqi," ISEM 4, no. 2 (2019): 248.

54 Masyhud and Rahmawati, Rahasia Sukses 3 Hafizh Qur'an Cilik Mengguncang Dunia, 224-28.

55 Dr. Kamil El-Laboody, Al-Mawad Al-Ta'limiyyah Fi Al-Daurah Al-Tadribiyyah Li Al-Muyassiri Wa AlMuyassirat Ala Manhaj Tabarak Al-Marhalah Al-Tsaniyah (Surabaya: YIKTY, 2017), 12.

${ }^{56}$ Aida Hidayah, "Metode Tahfidz Al-Qur'an Untuk Anak Usia Dini (Kajian Atas Buku Rahasia Sukses 3 Hafizh Quran Cilik Mengguncang Dunia)," Jurnal Studi Ilmu-Ilmu Al-Qur'an Dan Hadis 18, no. 1 (2017): 51-70, https://doi.org/10.14421/qh.2017.1801-04.

57 Masyhud and Rahmawati, Rahasia Sukses 3 Hafizh Qur'an Cilik Mengguncang Dunia, 21.
} 
He founded the Nurul Qulub Foundation, which is engaged in social, religious, and community activities. Among the flagship programs he was born was a toddler tahfiz institution named Markaz Tabarak. ${ }^{58}$ This established institution uses the tahfiz method adopted from the family system itself. This method came to be known as the Tabarak method because it is associated with the first child of al-Laboody. He built his learning process first. In addition, el-Laboody was active in various da'wa activities and religious studies in Egypt. He was better known as an Islamic thinker "al-Mufakkir alIslamy" than a pharmacist who became a professional before. He memorized the Quran when he was young. El-Laboody is married to Rasya al-Jayyar, who is also a pharmacist. As a husband, elLaboody acted head family and became a teacher to his wife and children. After marriage, she began memorizing the Quran from the beginning of surat al-Baqarah to the end of surat an-Nisa until his wife conceived their first child. At first, the el-Laboody family did not make his son memorize the Quran but only taught him to remember a short surah. The first surah memorized is surah alFatihah, followed by al-Mu'awwizat, namely an-Nas, al-Falaq, and al-Ikhlas, and the verse of al-kursi. After seeing the potential of Tabarak in memorizing something he heard, el-Laboody had a desire to make Tabarak a hafiz. ${ }^{59}$

For juz 30, el-Laboody always do the talqin to Tabarak 20 times, listening to the sheikh's reading through VCD. Hit and memorize Juz 29 with the rules of conscience. The next step is to start remembering from surat al-Baqarah onwards to khatam 30 juz at 4.5 years. All the memorization activities are recorded in a daily diary. That diary is becoming a memorization prototype for his two younger siblings, Yazid and Zeenah. They can both follow Tabarak can complete at the age of 4.5 years.

The right time in memorizing a new verse is after the dawn prayer. The time to repeat the Quran that has been memorized before is after the praying of Ashar. To maintain memorization after the child has memorized 30 juz, the el-Laboody family performs muraja'ah every day, which they call daily wird. This daily wird is a routine activity that should not be left in any condition. For example, when they make a long trip abroad, their daily wird is always done. They do the daily wird no less than three juz every day. They do this daily wird together after the dawn prayer, where the mind is still fresh after resting all night.60

While accompanying his children, the diaries memorized the Quran, used as the tahfiz method with the name of the Tabarak method. This method is developed and arranged into modules and curriculum tahfiz, taught in facilitator training, and applied in Markaz tahfiz. That was done because el-Laboody did not want the success to be enjoyed only by his family. 61

\section{Da'wa to Children with the Tabarak Method}

In this industrial era 4.0, Muslim society, especially parents, scholars, teachers, and da'wa activists, must have an ishfaq (caring) attitude towards children the next generation of Islam. The actual implementation of ishfaq is to educate children to read and memorize the Quran. By instilling a child's love for the Quran from an early age, then the love will blossom when growing up. Children are also not much burdened with life problems early, and memory is still strong. Various methods of memorizing the Quran were developed to make it easier for someone to memorize the Quran, including the Tabarak method. ${ }^{62}$

The Tabarak method has the vision of "The majority of children under five in Muslim countries become qurro' and proficient quranic memorizers when the age of seven." The mission is "To make

\footnotetext{
${ }^{58}$ Kamil El-Laboody, Al-Mawad Al-Ta'limiyyah Fi Al-Daurah Al-Tadribiyyah Li Al-Muyassiri Wa Al-Muyassirat Ala Manhaj Tabarak Al-Marhalah Al-Tsalitsah (Surabaya: YIKTY, 2018), 5.

${ }^{59}$ Hidayah, "Metode Tahfidz Al-Qur'an Untuk Anak Usia Dini (Kajian Atas Buku Rahasia Sukses 3 Hafizh Quran Cilik Mengguncang Dunia)," 62-67.

${ }^{60}$ Hidayah, "Metode Tahfidz Al-Qur'an Untuk Anak Usia Dini (Kajian Atas Buku Rahasia Sukses 3 Hafizh Quran Cilik Mengguncang Dunia)."

${ }^{61}$ El-Laboody, Al-Mawad Al-Ta'limiyyah Fi Al-Daurah Al-Tadribiyyah Li Al-Muyassiri Wa Al-Muyassirat Ala Manhaj Tabarak Al-Marhalah Al-Tsalitsah, 4.

${ }^{62}$ Roisa Toifaturrosyida, “Tahfidz Al-Qur'an Terhadap Balita Implementasi Metode Tabarak Tahfidz AlQur'an Terhadap Balita" (Universitas Islam Negeri Maulana Malik Ibrahim, 2020), xv.
} 
the generation of hafiz al-Quran since toddlers (from the age of 3-7 years)".63 The Tabarak method is a learning program that aims to make children memorize the Quran early by directing them to become a generation that benefits themselves, their communities, and their countries. ${ }^{64}$ From the Tabarak methods vision and mission, it is known that there is an element of da'wa to Muslims about the ease of memorizing the Quran for children. The Tabarak method can support children in memorizing the Quran. This method trains children to memorize the Quran according to their age, especially toddlers under the age of 5 years, and cannot read the Quran. That is by the theory that toddlers are a golden age. It's a picture of what he was taught. Therefore, educating and preaching to children from an early age will undoubtedly be more accessible. Steps and methods of memorizing the Quran with the Tabarak method include Sincere intention to seek Allah's pleasure, pray at mustajab time, determine the daily schedule, and prepare a wrapped gift box. 65

The parable of memorizing the Quran is like building a house 30 stories high. The first step that must be considered is a solid foundation to become sturdy and not collapse easily. For elLaboody, the foundations of the building are juz 'Amma (30) and juz Tabarak (29). Thus, memorization must start from the two juz, which must be completely mastered properly. Memorization begins with the letter an-Naba' from Juz' Amma in order in mushaf, rather than starting from short letters in general.

This Tabarak Education Program is applied to different levels of education for children, both Arabs and non-Arabs, who are targeted to memorize the Quran 30 juz. ${ }^{66}$ The Tabarak method consists of 7 levels: Level one with memorization material juz Amma and letters of hope and tanwin. Level 2 with Juz 29 material and learn to read. Level 3 with the material Surat al-Baqarah and Ali Imron. Level 4 with the material Surat al-Nisa to Surat al-Anfal. Level 5 Surat al-Taubah to Surat Taha. Level 6 from Surat al-Anbiya' to Surat Fathir. Level 7 of Surat Yasin and Surat al-Tahrim. ${ }^{67}$ Each class has learning hours and takes an average of four months to complete. If the child follows the level with good, then he can memorize the Quran in 2.5 years.

Each day consists of four hours. The first hour begins with al-Fatihah then continues with muraja'ah on the verses that have been memorized yesterday. The second hour of preparation is memorizing the new Quran verses and breakfast in milk and dates. Hours when the memorization was strengthening session today accompanied by light exercise as needed. A closing prayer accompanies the fourth hour of the introduction to tomorrow's material. In this process of learning to memorize, children are required to sit in an orderly manner. Within a week, the children became accustomed to sitting in an orderly manner. ${ }^{68}$ Habituation early on about sitting in an orderly manner is essential so that children can focus on listening to the verses played through VCD.

The existence of measurable modules and curricula makes this method can be developed in the community quickly. The training is held for facilitators at each level. The Tabarak method can be applied according to the module well, and the students can achieve memorization according to their targets. In training, el-Laboody, as the inventor of the Tabarak method, has always been a trainer. That is done so that the participants can directly get an explanation from the initiator of this method.

Media use in learning is essential to make it easier for children to receive rote material. The media used in Markaz Tabarak is diverse. Some are in the form of hardware, and some are in the form of software. Existing hardware consists of projectors (LCDs/ LEDs), children's game tools, letter cards, and balloon toys. The software consists of video talqin Sheikh Kamil el-Laboody, audio sheikh al-Hushary and as-Syuraim or as-Sudais, and verse program as a media device. The method

\footnotetext{
63 Laboudy, "Muzakarah Al-Daurah Al-Tadribiyyah Li Manhaj Tabarak Al-Marhalah Al-Ula,” 234.

${ }^{64}$ Masyhud and Rahmawati, Rahasia Sukses 3 Hafizh Qur'an Cilik Mengguncang Dunia, 88.

${ }^{65}$ Ayu Wulandari, "Penerapan Metode Tabarak Dalam Mendukung Anak Menghafal Al-Qur'an Di Rumah Tahfidz Balita Al-Utrujjah Malang” (University of Muhammadiyah Malang, 2019), ix.

66 Masyhud and Rahmawati, Rahasia Sukses 3 Hafizh Qur'an Cilik Mengguncang Dunia, 88.

${ }^{67}$ El-Laboody, Al-Mawad Al-Ta'limiyyah Fi Al-Daurah Al-Tadribiyyah Li Al-Muyassiri Wa Al-Muyassirat Ala Manhaj Tabarak Al-Marhalah Al-Tsaniyah, 3.

${ }^{68}$ Laboudy, “Muzakarah Al-Daurah Al-Tadribiyyah Li Manhaj Tabarak Al-Marhalah Al-Ula,” 71.
} 
used is with the talqin way repeatedly up to 20 times every day. Then listen to the reading of the verse from the CD recordings of the famous qari', namely al-Hushari, al-Minshawy, as-Sudais, and as-Syuraim. The next step is to use the Nuraniyah method, which reads the Quran by looking at mushaf. After that, it uses two senses, namely the ears and the eyes. That is a development of the traditional method.

The implementation of memorization of the Quran with the Tabarak method is generally carried out based on the mechanisms listed in the curriculum, namely: First, the general muraja'ah or muraja'ah kubra that is to read the verses to be memorized. Second, Talaqqi through the medium of learning videos read by Sheikh Kamil. He recited with the emphasis of reading according to the maxim of the surah, then exemplified by the children and repeated by verse 3 repetitions. Third, continued with a special muraja'ah, this muraja'ah only focuses on reciting verses memorized verses using the application of verses. Fourth, the teachers conduct intensive guidance from each student. ${ }^{69}$

The teaching of the Quran that begins early will be more accessible because the child's mind is still clean, and the child's memory is still strong. Many parents put their children into the tahfiz house, hoping that their child would become a hafiz. But in fact, many tahfiz places still use less precise and effective methods so that children will feel bored quickly and saturated. ${ }^{70}$ For children, this Tabarak method is quite effective in helping children memorize the Quran. In addition, the role of parents is significant in the success of memorizing the Quran with the Tabarak method.

In the Tabarak method, there is a meeting of student guardians called Majlis al-aba' wa majlis al-Ummahat (forum of student guardians). ${ }^{71}$ At this event, parents can share and motivate each other to remain committed to this child's tahfiz. This forum is adequate to maintain parents' commitment so that their children can become hafiz of the Quran. In addition, in the Tabarak method module, there are also directions or instructions for parents in educating their children. In the instructions listed about the differences of education in the past and present, the need to understand the problem from the child's perspective, teach the child about cleanliness, overcome the child's jealousy of his brother and others. ${ }^{72}$

The success of children memorizing the Quran affects parents, families, and surrounding environments. Many parents do not initially memorize the Quran. Still, because they often accompany their children during memorization of the Quran, they can finally memorize the Quran as much as their children memorize them. ${ }^{73}$ That indicates that preaching by teaching the Quran to children can also positively impact the environment. The Tabarak family, which started from the family program, became global as the slogan "from family to the ummah." Although the Tabarak method is identical to the tahfiz Quran, other lessons are included in the curriculum. Some teachers recognize that teaching tahfiz to children affects good behavior to children and increases children's love for the Quran. Ustazah Ida, Director of Markaz al-Firdaus, stated that if initially good, then the next will be good too. ${ }^{74}$ That is inseparable from the slogan taught in the Tabarak method, namely nawwiru bi al-Quran qulubakum (Shine your heart with the Quran). ${ }^{75}$

\footnotetext{
${ }^{69}$ Fi Iisya Muthaharah, "Implementasi Metode Tabarak Dalam Meningkatkan Hafalan Al-Qur'an Bagi Anak Balita Pada Juz 29 Dan 30 Di Rumah Tahfidz Rutaba Sukun Kota Malang," Journal Islamic Studies 1, no. 1 (2020): 1.

${ }^{70}$ Hailatur Rosida, "Penerapan Metode Tabarak Dalam Meningkatkan Hafalan Para Remaja Di Rumah Tahfidz Gemilang Indonesia Cabang Salatiga," xv.

${ }^{71}$ El-Laboody, Al-Mawad Al-Ta'limiyyah Fi Al-Daurah Al-Tadribiyyah Li Al-Muyassiri Wa Al-Muyassirat Ala Manhaj Tabarak Al-Marhalah Al-Tsaniyah, 12.

72 Laboudy, "Muzakarah Al-Daurah Al-Tadribiyyah Li Manhaj Tabarak Al-Marhalah Al-Ula," 72-120.

73 El-Laboody, Al-Mawad Al-Ta'limiyyah Fi Al-Daurah Al-Tadribiyyah Li Al-Muyassiri Wa Al-Muyassirat Ala Manhaj Tabarak Al-Marhalah Al-Tsalitsah, 5.

${ }^{74}$ Ida Husnur Rahmawati, “Direktur Markaz Al-Firdaus," Interview, September 10, 2021.

75 Laboudy, "Muzakarah Al-Daurah Al-Tadribiyyah Li Manhaj Tabarak Al-Marhalah Al-Ula,” 17.
} 
Memorizing the Quran is not easy. ${ }^{76}$ The children who learn to use the Tabarak method do not all successfully memorize according to the target. That depends on several factors, namely supporting factors and inhibitions. In the Tabarak method, four elements affect the success of children's tahfiz: parents, facilitators, children, and curriculum. ${ }^{77}$ The curriculum of the Quran will not change, children are also easily controlled, but facilitators and especially parents have a major determining factor in the success of children. Parents' tendencies often change and affect their commitment to making their children memorize the Quran. ${ }^{78}$ The role of teachers and parents is significant to support memorization skills in children. ${ }^{79}$ That is seen when his parents guide the child to muraja'ah at home; the results are better than the child who does not do muraja'ah at home. ${ }^{80}$ That requires direct contact that can be realized in the form of parental support for their children. 81

The use of social media also plays a role in the spread of this Tabarak method, such as WhatsApp, Facebook, Instagram, and Youtube. It is part of the proselytizing media to spread kindness to others and the community.

\section{E. Conclusion}

Based on the discussion of the above research results, it concluded that the Tabarak method could be used as a means of da'wa to facilitate children's memorization of the Quran in various tahfiz institutions. This method is suitable for children, especially those who cannot read. However, gradually children are also taught to read, and when they are adept at reading, it is increasingly supportive of the ease of the child to complete his memorization. It teaches good behavior to guide the morals of Muslim children. The support of infrastructure facilities, teachers, children, and parents is very influential in completing their memorization.

Based on the results of this study, recommendations/suggestions can be given: first to the stakeholders Markaz users of the Tabarak method to remain consistent in applying the Tabarak method according to the curriculum made. Second, to the next researcher to research with other methods such as action research, experimental research, or survey research with subjects and a more comprehensive sample population.

\section{References}

Abdillah, Siti Anna Farhiana. "Implementasi Metode Tabarak Dalam Pembelajaran Menghafal AlQur'an Pada Anak Hambatan Speech Delay Di Rutaba Shohibul Qur'an.” Universitas Negeri Malang, (2020).

Akbar, Ali, and Hidayatullah Ismail. "Metode Tahfidz Al-Qur'an Di Pondok Pesantren Kabupaten Kampar." Jurnal Ushuluddin 24, no. 1 (2016): 91-102.

\footnotetext{
${ }^{76}$ S. Aisyah Sufian et al., "The Impacts of Covid-19 to the Situation of Malaysian Education," International Journal of Academic Research in Progressive Education and Development 9, no. 2 (2020): 634, https://doi.org/10.6007/ijarped/v9-i2/7659.

${ }^{77}$ Laboudy, "Muzakarah Al-Daurah Al-Tadribiyyah Li Manhaj Tabarak Al-Marhalah Al-Ula," 236.

78 Rahmawati, "Direktur Markaz Al-Firdaus."

${ }^{79}$ El-Laboody, Al-Mawad Al-Ta'limiyyah Fi Al-Daurah Al-Tadribiyyah Li Al-Muyassiri Wa Al-Muyassirat Ala Manhaj Tabarak Al-Marhalah Al-Tsaniyah, 12.

${ }^{80}$ Rini Puji Astutik, "Bimbingan Kelompok Menghafal Al- Qur'an Dengan Metode Tabarak Pada Santri Rumah Tahfidz Amanah Sragen" (Fakultas Ushuluddin Dan Dakwah Institut Agama Islam Negeri Surakarta, 2020), 69.

${ }^{81}$ Rosyidah Umpu Malwa, "Dukungan Sosial Orangtua Dengan Motivasi Belajar Siswa Putra Tahfidz AlQur'an," Psikis: Jurnal Psikologi Islami 3, no. 2 (2017): 138, https://doi.org/10.19109/psikis.v3i2.1758.
} 
https://doi.org/10.24014/jush.v24i1.1517.

Alivanie, Naylusshofy. "Strategi Guru Dalam Pembelajaran Menghafal Juz 'Amma Pada Anak Usia Dini Di TK Islam Al Azhar Kepatihan Tulungagung." Institut Agama Islam Negeri Tulungagung, (2021).

Aminah. "Strategi Dakwah Dalam Memotivasi Anak Untuk Menghafal Surat-Surat Pendek Taman Kanak-Kanak Mandiri Jakabaring.” Universitas Muhammadiyah Palembang, (2019).

Andarini, Nurul Hidayah. "Pengaruh Menghafal Al-Qur'an Metode Tabarak Terhadap Peningkatan Memori Menghafal Al-Qur'an Pada Anak Usia Dini.” Universitas Islam Negeri Maulana Malik Ibrahim, http://dx.doi.org/10.1053/j.gastro.2014.05.023\%0Ahttps://doi.org/10.1016/j.gie.2018.0 4.013\%0Ahttp://www.ncbi.nlm.nih.gov/pubmed/29451164\%0Ahttp://www.pubmedcen tral.nih.gov/articlerender.fcgi?artid=PMC5838726\%250Ahttp://dx.doi.org/10.1016/j.gie. 2013.07.022.

Awang, Arita Hanim, Nurlelawati Ab Jalil, Nurul Hamiruddin Salleh, Habibah Ab Jalil, and Siti Suria Salim. "Physical Learning Ecosystem And Built Environment Of Tahfiz Institutions In Malaysia: A Systematic Review." Journal Of Architecture, Planning \& Construction $\begin{array}{lllll}\text { Management } & 9, & \text { no. } & 1 & \text { (2019): }\end{array}$ https://journals.iium.edu.my/kaed/index.php/japcm/article/view/354.

Badruzaman, Dudi. "Metode Tahfidz Al-Qur'an Di Pondok Pesantren Miftahul Huda II Kabupaten Ciamis." Jurnal KACA 9, no. 2 (2019): 184-93. https://doi.org/10.29313/idea.v0i0.4888.

“Daftar Lembaga Tahfidz Quran Metode Tabarak Di Indonesia,” 2019.

Dzulkarnain, Ahmad A.A., Amirah K. Azizi, and Nur H. Sulaiman. "Auditory Sensory Gating in Huffaz Using an Auditory Brainstem Response with a Psychological Task: A Preliminary Investigation." Journal of Taibah University Medical Sciences 15, no. 6 (2020): 495-501. https://doi.org/10.1016/j.jtumed.2020.08.007.

El-Laboody, Dr. Kamil. Al-Mawad Al-Ta'limiyyah Fi Al-Daurah Al-Tadribiyyah Li Al-Muyassiri Wa Al-Muyassirat Ala Manhaj Tabarak Al-Marhalah Al-Tsaniyah. Surabaya: YIKTY, (2017).

El-Laboody, Kamil. Al-Mawad Al-Ta'limiyyah Fi Al-Daurah Al-Tadribiyyah Li Al-Muyassiri Wa AlMuyassirat Ala Manhaj Tabarak Al-Marhalah Al-Tsalitsah. Surabaya: YIKTY, (2018).

Fahmi. "Peranan Dakwah Dalam Meminimalisir Kenakalan Remaja Di Kecamatan Bati-Bati Kabupaten Tanah Laut." UIN Antasari Banjarmasin, (2020). http://repositorio.unan.edu.ni/2986/1/5624.pdf.

Fatmawati, Eva. "Manajemen Pembelajaran Tahfidz Al-Qur'an." ISEMA: Islamic Educational Management 4, no. 1 (2019) : 25-38. https://doi.org/10.15575/isema.v3i2.5255.

Hailatur Rosida. "Penerapan Metode Tabarak Dalam Meningkatkan Hafalan Para Remaja Di Rumah Tahfidz Gemilang Indonesia Cabang Salatiga." Fakultas Tarbiyah Dan Ilmu Keguruan Institut Agama Islam Negeri Salatiga, (2020).

Herma, Tendri, Umi Kusyairy, and Muh Rusdi T. "Analisis Penerapan Metode Tabarak Menghafal Al-Qur'an Juz 30 Di Sekolah Tahfidz Al-Husna Balita Dan Anak Makassar." NANAEKE: Indonesian Journal of Early Childhood Education 3, no. 1 (2020): 37-48. https://doi.org/10.24252/nananeke.v3i1.14332.

Hidayah, Aida. "Metode Tahfidz Al-Qur'an Untuk Anak Usia Dini (Kajian Atas Buku Rahasia Sukses 3 Hafizh Quran Cilik Mengguncang Dunia)." Jurnal Studi Ilmu-Ilmu Al-Qur'an Dan Hadis 18, no. 1 (2017): 51-70. https://doi.org/10.14421/qh.2017.1801-04.

Hidayah, Nurul. "Strategi Pembelajaran Tahfidz Al-Qur'an Di Lembaga Pendidikan." Ta'allum: 
Jurnal Pendidikan Islam 4.1 (2016): 63-81. https://doi.org/10.21274/taalum.2016.4.1.6381.

Hikmah, Siti. "Mengenalkan Dakwah Pada Anak Usia Dini." Jurnal Ilmu Dakwah 34, no. 1 (2014): 63-76.

Juliana, Ria, and Ridwan Arifin. "Anak Dan Kejahatan (Faktor Penyebab Dan Perlindungan Hukum)." Jurnal Selat 6, no. 2 (2019): 225-34. https://doi.org/10.31629/selat.v6i2.1019.

Kartika, Tika. "Manajemen Pembelajaran Tahfidz Al-Qur'an Berbasis Metode Talaqqi." ISEM 4. 2 (2019): 245-56.

Khairi, Ahmad Imam. "Masyarakat Modern Dan Kenakalan Remaja: Suatu Telaah Sosial." ENTITA: Jurnal Pendidikan Ilmu Pengetahuan Sosial Dan Ilmu-Ilmu Sosial 2, no. 1 (2020): 147-69. https://doi.org/10.19105/ejpis.v1i2.3243.

Laboudy, Kamil el. "Muzakarah Al-Daurah Al-Tadribiyyah Li Manhaj Tabarak Al-Marhalah Al-Ula." Jakarta: YIKTY, (2019).

Lau, Masrudin. "Evektifitas Metode Tabarok Dalam Memepercepat Anak Menghafal Al-Qur'an Di Club Tahfid Genta Qur'an Bubutan Surabaya." Revista Brasileira de Geografia Física. Universitas Muhammadiyah Surabaya, (2016). http://biblioteca.ibge.gov.br/visualizacao/monografias/GEBIS - RJ/RBG/RBG 1995 v57_n1.pdf\%0Ahttps://periodicos.ufpe.br/revistas/rbgfe/article/view/234295.

Lubis, Awwaliya Mursyida, and Syahrul Ismet. "Metode Menghafal Alquran Pada Anak Usia Dini Di Tahfidz Center Darul Hufadz Kota Padang." Aulad: Journal on Early Childhood 2, no. 2 (2019): 8-14. https://doi.org/10.31004/aulad.v2i2.30.

Mahfud, Mokhamad, and Rama Kertamukti. "Desain Komunikasi Dakwah Visual Animasi 2D Untuk AnaK (Studi Deskriptif Kualitatif Di SDN Monggang Pendowoharjo Sewon Bantul).” Profetik Jurnal Komunikasi 09. (2016): 45-64.

Mahmud, Rudi. "Strategi Dakwah Pada Anak Usia Dini Di TK Darul Hikmah Desa Tongke-Tongke Kecamatan Sinjai." UIN Alauddin Makassar. (2018).

Maksum, Khanif, and Ahmad Syamsul Arifin. "Pola Pendekatan Penanganan Gangguan Perilaku (Conduct Disorder) Pada Pelajar SD: Sebuah Upaya Mengurangi Perilaku Kekerasan Pelajar Di Yogyakarta." MODELING: Jurnal Program Studi PGMI Volume 6. 2 (2019): 259-77.

Malwa, Rosyidah Umpu. "Dukungan Sosial Orangtua Dengan Motivasi Belajar Siswa Putra Tahfidz Al-Qur'an." Psikis: Jurnal Psikologi Islami 3.22 (2017): 137-44. https://doi.org/10.19109/psikis.v3i2.1758.

Mardiana. "Komunikasi Dakwah Kultural Di Era Millenial." Alhadharah: Jurnal Ilmu Dakwah 19. 1 (2020): $\quad$ 90-101. antasari.ac.id/index.php/alhadharah/article/view/3858.

http://jurnal.uin-

Marlista. "Efektivitas Metode Tabarak Dalam Meningkatkan Memori Menghafal Al-Qur'an Pada Anak Usia Dini Di Rumah Tahfidz Shohibul Qur'an Manado.” IAIN Manado, (2020).

Masyhud, Fathin, and Ida Husnur Rahmawati. Rahasia Sukses 3 Hafizh Qur'an Cilik Mengguncang Dunia. Jakarta: Zikrul Hakim, (2019).

Maula, Rifdatul. "Implementasi Metode Tabarak Di Mataba Al Furqon Desa Petung Panceng Gresik Dan Metode Talaqqi Di KB-TK Al Furqon Al Islami Desa Srowo Sidayu Gresik." Pascasarjana UIN Sunan Ampel Surabaya, (2019).

Mudhakiroh, Nurul. "Metode Menghafal Al-Qur'an Pada Rumah Tahfidz Izzatul Qur'an As'adiyah Dan Al-Malik Samarinda." Program Pascasarjana, Institut Agama Islam Negeri Samarinda, (2020). 
Muslimin, Achmad. "Implementasi Metode Halaqah Dan Resitasi Dalam Tahfidz Al-Quran Di Sdit El - Haq Banjarsari Buduran Sidoarjo." Adabiyah : Jurnal Pendidikan Islam 1.1 (2011): 5562. https://doi.org/10.21070/ja.v1i1.164.

Muthaharah, Fi Iisya. "Implementasi Metode Tabarak Dalam Meningkatkan Hafalan Al-Qur'an Bagi Anak Balita Pada Juz 29 Dan 30 Di Rumah Tahfidz Rutaba Sukun Kota Malang." Journal Islamic Studies 1.1 (2020).

Ni Putu Rai Yuliartini. "Kenakalan Anak Dalam Fenomena Balapan Liar Di Kota Singaraja Dalam Kajian Kriminologi." Jurnal Advokasi 9.1 (2019): 31-43.

Nurma Putri Juwita, Roza. "Efektivitas Metode Tabarak Dalam Pembelajaran Tahfiz Al-Quran Pada Balita Di Markaz Al-Firdaus Candi Sidoarjo.” Universitas Muhammadiyah Sidoarjo, (2018).

Prayuda, Angga. "Peran Kepolisian Sektor Simpang Kanan Dalam Menanggulangi Kenakalan Remaja." Universitas Islam Negeri Sultan Syarif Kasim Riau, (2021).

Rachman, Arief, and Ismi Nadiyati. "Dakwah Melalui Film Animasi." ORASI: Jurnal Dakwah Dan Komunikasi 9.2 (2018): 29-42. https://doi.org/10.24235/orasi.v9i2.3690.

Rahmawati, Ida Husnur. “Direktur Markaz Al-Firdaus.” Interview. September 10, (2021).

Riamah, and Elfa Zuriana. "Faktor-Faktor Yang Mempengaruhi Terjadinya Kenakalan Remaja." Menara Ilmu XII. 10 (2018): 47-51.

Rini Puji Astutik. "Bimbingan Kelompok Menghafal Al- Qur'an Dengan Metode Tabarak Pada Santri Rumah Tahfidz Amanah Sragen." Fakultas Ushuluddin Dan Dakwah Institut Agama Islam Negeri Surakarta, (2020).

Rusmalita, Santa. “Internalisasi Nilai-Nilai Dakwah Pada Anak Usia.” Al-Hikmah: Jurnal Dakwah 11. 2 (2017): 179-86.

Sanusi, M., Nurhasanah, and Nurbaity. "Hubungan Komitmen Pendidikan Diniah Dengan Perilaku Menyimpang Pada Remaja." Jurnal Ilmiah Mahasiswa Bimbingan Dan Konseling 2.2 (2017): 56-61.

http://linkinghub.elsevier.com/retrieve/pii/S0167273817305726\%0Ahttp://dx.doi.org/ 10.1038/s41467-017-01772-

1\%0Ahttp://www.ing.unitn.it/ luttero/laboratoriomateriali/RietveldRefinements.pdf\%0 Ahttp://www.intechopen.com/books/spectroscopic-analyses-developme.

Sarmin Husaini. "Strategi Dakwah Dalam Meminimalisir Kenakalan Remaja Di Kelurahan Katangka Kab. Gowa." Universitas Muhammadiyah Makassar, (2019).

Sri Wahyuni Kadir, Nursalam, and Muhammad Akhir. "Peranan Polisi Sektor Kajuara Dalam Menanggulangi Kenakalan Remaja." Fenomena Plagiarisme Mahasiswa IV. (2016): 87-95. https://media.neliti.com/media/publications/70308-ID-fenomena-plagiarismemahasiswa.pdf.

Sufian, S. Aisyah, N. Adilah Nordin, S. Shafia Nazar Tauji, and M. Khalid M. Nasir. "The Impacts of Covid-19 to the Situation of Malaysian Education." International Journal of Academic Research in Progressive Education and Development 9. (2020). https://doi.org/10.6007/ijarped/v9-i2/7659.

Sugiestian, Novita. "Peran Dakwah Dalam Problematika Masa Remaja." OSF PREPRINTS, (2012). https://doi.org/10.31219/osf.io/c7xwh.

Sukardi, Akhmad. "Metode Dakwah Dalam Menangani Problematika Remaja." Al-Munzir 9. (2016): 12-28. https://ejournal.iainkendari.ac.id/index.php/al-munzir/article/view/774/705\#.

Toifaturrosyida, Roisa. “Tahfidz Al-Qur'an Terhadap Balita Implementasi Metode Tabarak Tahfidz Al-Qur'an Terhadap Balita." Universitas Islam Negeri Maulana Malik Ibrahim, (2020). 
Wasyik, Torikhul, and Abdul Hamid. "Implementasi E-Learning Dalam Pembelajaran Al-Qur'an Era Covid-19 Di Sanggar Tahfidz Enterpreuner Krian Sidoarjo." Edudeena 4. (2020): 13-24.

Wulandari, Ayu. "Penerapan Metode Tabarak Dalam Mendukung Anak Menghafal Al-Qur'an Di Rumah Tahfidz Balita Al-Utrujjah Malang." University of Muhammadiyah Malang, (2019).

Zuhurudeen, Fathima Manaar, and Yi Ting Huang. "Effects of Statistical Learning on the Acquisition of Grammatical Categories through Qur'anic Memorization: A Natural $\begin{array}{lcc}\text { Experiment." } & \text { Cognition } & 148 \\ \text { https://doi.org/10.1016/j.cognition.2015.12.014. }\end{array}$

(2016):

79-84. 